\title{
Hammer Chyme: The Russian-Doll Effect Limits Reconstructing Marine Trophic Food Webs
}

Mark de Bruyn ( $\square$ mark.debruyn@sydney.edu.au )

The University of Sydney

\section{Matteo Barbato}

The University of Sydney

Joseph D. DiBattista

Australian Museum Research Institute

Matt K. Broadhurst

Southern Cross University

\section{Research Article}

Keywords: DNA metabarcoding, ecological niche, diet, elasmobranch, marine, predator

Posted Date: April 30th, 2021

DOI: https://doi.org/10.21203/rs.3.rs-465807/v1

License: (c) (i) This work is licensed under a Creative Commons Attribution 4.0 International License. Read Full License 
1 Hammer chyme: the Russian-doll effect limits reconstructing marine trophic food webs

2

3 Mark de Bruyn", ${ }^{1, *}$, Matteo Barbato ${ }^{1,2}$, Joseph D. DiBattista ${ }^{3}$, and Matt K. Broadhurst ${ }^{4,5, *}$

4

5 Affiliations:

$6{ }^{1}$ The University of Sydney, School of Life and Environmental Sciences, Sydney, NSW 2006,

$7 \quad$ Australia.

$8 \quad{ }^{2}$ Department of Biology, University of Padova, Padova, Italy.

$9{ }^{3}$ Australian Museum Research Institute, Australian Museum, 1 William Street, Sydney, NSW 10 2010, Australia.

$11{ }^{4}$ NSW Department of Primary Industries, Fisheries Conservation Technology Unit, National 12 Marine Science Centre, Southern Cross University, 2 Bay Drive, Coffs Harbour, NSW 2450,

13 Australia.

$14{ }^{5}$ Marine and Estuarine Ecology Unit, School of Biological Sciences, University of 15 Queensland, St Lucia, Australia.

16

* Corresponding authors: mark.debruyn@sydney.edu.au \& matt.broadhurst@dpi.nsw.gov.au

ORCID: de Bruyn (0000-0003-1528-9604); Barbato (0000-0001-5368-2090), DiBattista

(0000-0002-5696-7574); and Broadhurst (0000-0003-0184-7249)

Keywords: DNA metabarcoding, ecological niche, diet, elasmobranch, marine, predator 


\section{Abstract}

27 Increasing fishing effort, including bycatch and discard practices, are impacting marine biodiversity, particularly among slow-to-reproduce taxa such as elasmobranchs, and specifically sharks. While some fisheries involving sharks are sustainably managed, collateral mortalities continue, contributing towards $>35 \%$ of species being threatened with extinction. To effectively manage shark stocks, life-history information, including resource use/feeding ecologies is pivotal, especially among those species with wide-ranging distributions and habitats. Two cosmopolitan sharks bycaught off eastern Australia are the common blacktip shark (Carcharhinus limbatus; globally classified as Near Threatened) and great hammerhead (Sphyrna mokarran; Critically Endangered). We opportunistically sampled the digestive tracts of these two species and also any whole prey; (termed the 'Russian-doll' approach) caught in bather-protection gillnets off northern New South Wales to investigate their regional feeding ecologies and the capacity for DNA metabarcoding to delineate trophic interactions. Sphyrna mokkaran fed predominantly on Myliobatiformes and Rajiformes, but also teleosts, while $C$. limbatus mostly consumed teleosts, with some inter-specific dietary overlap of prey items. Extensive cross-contamination of predator and prey digestive tracts, likely via the predator's stomach chyme, was evident from the metabarcoding assays limiting the opportunity to delineate trophic interactions from these data. This Russian-doll effect requires further investigation in DNA metabarcoding studies focused on dietary preferences, but implies any outcomes will need to be interpreted concomitant with traditional visual approaches. 
Global biodiversity is under threat, with accelerating losses of species and increasing concern about ecosystem changes (Diaz et al., 2020). In the oceans, escalating fishing effort and associated bycatches and discarding practices are impacting on marine biodiversity (Jones et al., 2020). Levels of extinction threat vary regionally and by taxonomic group, but owing to their low reproductive rates and late age-at-maturity, elasmobranchs, especially sharks, are among those taxa highly susceptible to increasing anthropogenic pressures (Dulvy et al., 2014). More specifically, among the total known species of 'ground sharks' or the Carcharhiniformes $(n=287), 36 \%$ are listed as threatened with extinction, and a further $18 \%$ are classified as 'Data Deficient' (IUCN, 2018).

In Australia, several shark species are targeted in commercial gillnet fisheries (e.g. gummy sharks Mustelus antarcticus and sandbar sharks Carcharhinus plumbeus; Walker et al., 2005; Braccini et al., 2012) and also in bather-protection programs using gillnets and/or baited hooks (e.g. white Carcharodon carcharias, tiger Galeocerdo cuvier, and bull sharks Carcharhinus leucas; Sumpton et al., 2011; Broadhurst and Cullis, 2020). Various ancillary species also incur collateral mortalities as bycatch from the above and other commercial fishing activities (Stevens and Wayte, 2009; Roff et al., 2016, 2018).

65

Two of the more abundant, cosmopolitan Carcharhiniformes found in Australia and well represented in bycatches of bather-protection fishing gears (Sumpton et al., 2011, Broadhurst and Cullis, 2020) are the common blacktip shark (Carcharhinus limbatus) and great hammerhead (Sphyrna mokarran), which are globally classified as Near Threatened and Endangered, respectively (IUCN, 2018). Sphyrna mokarran is also registered in Appendix II 
precipitated their legislated protection across many jurisdictions. Notwithstanding these classifications, the biology and ecology of $S$. mokarran remain poorly understood, particularly their diet, which limits effectively managing their remaining stocks (Dulvy et al., 2014; Raoult et al., 2019; 2020).

Sharks are characterized by complex and plastic ecological roles at the highest levels of the food web (Heithaus et al., 2008). Their ontogeny induces a dietary shift through their life stages and they can prey on communities across different marine ecosystems (e.g. coastal, demersal and pelagic) depending on resource availability (Bizzarro et al. 2017). Because of their feeding role, the ecological importance of sharks is considered a form of top-down control. These direct (prey consumption) and indirect (behavioural, interaction and community dynamics) effects shape lower trophic communities. In both temperate and tropical ecosystems, it is useful to differentiate larger sharks into apex ( $>3.0 \mathrm{~m}$ total length; TL) or mesopredators ( 1.3 to $3.0 \mathrm{~m} \mathrm{TL}$ ) (Heupel et al., 2014).

Sphyrna mokarran can reach a maximum size of $6.0 \mathrm{~m}$ total length (TL) and in situ observations imply it predominantly feeds on rays (Chapman and Gruber, 2002; Cliff, 1995; Strong et al., 1990) but, like most of its apex congeners also consumes teleosts and other sharks (Mourier et al., 2013; Roemer et al., 2016). Nevertheless, data are limited and in a recent review Gallagher and Klimley (2018) stated that S. mokarran feeding ecology requires further assessment. Relatively more is known about the smaller, mesopredator $C$. limbatus (maximum TL of $\sim 2.6 \mathrm{TL}$ ), which typically feeds on teleosts throughout their cosmopolitan distributions (Barry et al., 2008; Tavares, 2008; Plumlee and Wells, 2016). Nevertheless, much of the research describing C. limbatus is restricted to the Atlantic Ocean and less is known about their foraging ecology off Australia. 
Shark feeding ecology has been quantified mainly by visual identification of stomach contents, biochemical techniques (e.g. stable isotope, lipid and amino acid signatures) or telemetry (e.g. satellite and acoustic tagging) via habitat association (Young et al., 2015).

Each of these methods has inherent strengths and weaknesses (reviewed in Leigh et al., 2017; Amundsen and Sánchez-Hernández, 2019). More recent innovations in genetic techniques, particularly high-throughput metabarcoding approaches, are now routinely contributing to our understanding of predator-prey relationships, and in general, providing improved taxonomic resolution of prey versus traditional methods (Alberdi et al., 2019; Nielsen et al., 2018; Pompanon et al., 2012). The DNA metabarcoding of digestive-tract contents is now commonplace in studies on terrestrial taxa (reviewed in Alberdi et al., 2019; Deagle et al., al., 2020; Sousa et al. 2016; Takahashi et al., 2020; Yoon et al. 2017).

A promising application of DNA metabarcoding for digestive-tract content analyses is in the 
regional diets, but also (2) further investigate the Russian-doll DNA metabarcoding application to trace trophic interactions in marine apex- and mesopredators.

\section{Material and Methods}

\section{Ethics declaration}

All experimental protocols were approved by New South Wales Fisheries, Australian Government Department of Primary Industries, and carried out in accordance with relevant guidelines and regulations. All methods reported are in accordance with ARRIVE guidelines (https://arriveguidelines.org).

\section{Sample collection}

The study was done using seven $S$. mokarran (three females and four males) and four $C$. limbatus (two of each sex) that died in bather-protection gillnets deployed off Lennox Head, Ballina, and Evans Head, NSW, Australia $\left(28.77^{\circ} \mathrm{S}, 153.60^{\circ} \mathrm{E}\right.$ to $\left.29.10^{\circ} \mathrm{S}, 153.44^{\circ} \mathrm{E}\right)$ between 7 February and 13 March, 2018 (Fig. 1). Each gillnet measured $150 \mathrm{~m}$ long $\times 4$ or 6 $\mathrm{m}$ deep and comprised 600- or 800-mm mesh made from either 1.8- or 2.1-mm diameter twisted polyethylene, or 2.5-mm diameter polyamide twine (see Broadhurst and Cullis, 2020 for details of the fishing gear).

Whole sharks were removed from the gillnets and stored at $-20^{\circ} \mathrm{C}$ (within 3 hours) until being necropsied in May 2018. During the necropsy process, specimens were defrosted for 12 hours and measured for TL before the stomach cavity was opened in a sterile field laboratory with bleach sterilized tools. All digestive contents were removed, with any animal matter identified (where possible), preserved in $100 \%$ ethanol, and stored at $-20^{\circ} \mathrm{C}$ until further analyses. Extraction controls for DNA (ultrapure water samples, Invitrogen, Waltham, USA) 
were collected in sterile $1.5 \mathrm{~mL}$ microcentrifuge tubes alongside the stomach-content samples and subjected to the same workflow described below.

\section{Stomach-content analyses and DNA extraction}

Whole prey removed from S. mokkaran and C. limbatus were identified by visual inspection, mostly to the species level. Some of the incomplete specimens, typically fish jawbones (Fig. 2) or scales, were identified to genus only. For each S. mokkaran and C. limbatus, the remainder of its unidentifiable stomach contents (both liquids and solids) were homogenised using a previously sterilised (washed with detergent, followed by a 10\% bleach wash, and rinsed thoroughly in MilliQ water) commercial food blender. The digestive-tract contents of any whole prey were separately homogenised as above.

For all samples, DNA was extracted from approximately $5 \mathrm{~mL}$ of the homogenate using a QIAamp PowerFecal DNA kit (Qiagen, Sydney, Australia) according to manufacturer's instructions. This kit effectively removes PCR inhibitors from fecal and stomach content samples. The DNA extraction was carried out in a pre-PCR laboratory to minimise contamination, and clean-room protocols were followed with extensive bleaching and UV treatment of the area and equipment for all laboratory steps. Filter pipette tips were used in all instances and gloves were frequently changed, particularly between handling specimens or plasticware.

\section{PCR amplification and Illumina sequencing}

The DNA extracts from each stomach sample were amplified, tagged separately, and then pooled for sequencing. Two group-specific mini-barcode primers were selected for the amplification of teleost and crustacean DNA, targeting 12S (MiFish: Miya et al., 2015) and 
16S (Crust16S short: Berry et al., 2017) mitochondrial DNA genes, respectively. We also used a universal 18S primer set (Zhan et al., 2013) targeting the hypervariable V4 region of the nuclear small subunit ribosomal DNA to amplify templates from a broader fraction of marine metazoans. Polymerase chain reaction (PCR) was performed using the AmpliTaq Gold 360 protocol and thermocycling conditions recommended in (Taberlet, et al., 2018). The PCR hybridization temperatures were 50,51 and $50^{\circ} \mathrm{C}$ for MiFish, Crust16S, and Uni18S primer sets, respectively, and products were run on a $1 \%$ agarose gel to confirm amplification of the correct target size (MiFish $= \pm 170 \mathrm{bp}$; Crust16S $= \pm 170 \mathrm{bp}$, Uni18S $= \pm 220 \mathrm{bp}$ ). A second round of PCR was undertaken with the cleaned PCR products using unique dualindexed primers for each sample, which included the Illumina-specific sequencing adaptors. PCR products were sent to the Ramaciotti Centre for Genomics at the University of NSW for cleaning, normalising, and pooling prior to paired-end sequencing, which was performed using a 500 cycle MiSeq V3 Reagent Kit on an Illumina MiSeq platform (Illumina, San Diego, CA, USA). Sample demultiplexing based on the incorporated indexes was conducted by the sequencing centre.

\section{Bioinformatic pipeline}

All sequence data were quality filtered prior to taxonomic assignment using the following tools: 1) Geneious v10.1.3 (https://www.geneious.com) for stitching R1 and R2 reads using default settings, trimming low quality reads from the $5^{\prime} / 3^{\prime}$ end (quality score $=30$ ), removing adapters, and filtering out reads below a minimum threshold length (150 bp for MiFish, $80 \mathrm{bp}$ for Crust16S, and 250 bp for Uni18S), 2) USEARCH (v11.0.667; Edgar, 2010) for renaming files and file format conversion (.fastq to .fasta), dereplication (identifying unique sequences), removing singletons, removing chimeric sequences, and generating a zero-radius operational taxonomic unit) (ZOTU) table with the UNOISE algorithm. 
The ZOTUs were queried against the National Centre for Biotechnology Information's

(NCBI) GenBank nucleotide database (accessed in 2020) using BLASTn with the following settings: percentage identity $=97$, query coverage $=100$, best hit score edge of 0.05 , best hit overhang of 0.25 , and an E-value of 1e-3. An additional, less-stringent data set was generated for each assay using the following BLASTn settings: percentage identity $=90$, query coverage $=95$, best hit score edge of 0.05 , best hit overhang of 0.25 , and an E-value of $1 \mathrm{e}-3$. The LULU algorithm (Frøslev et al., 2017) was then run to curate the assignments assessing sequence similarity and their co-occurrence patterns with the default parameters: minimum_ratio_type $=\min$, minimum_ratio $=1$, minimum $\_$match $=84$, minimum_relative_cooccurence $=0.95$. This entire process was completed on the Zeus SGI cluster based at the Pawsey Supercomputing Centre in Kensington, Western Australia using an in-house script developed by Mousavi et al., (2020). All raw sequencing data needed to replicate the study are available from Dryad Digital Repository XX.

\section{Results}

Four of the S. mokarran individuals had identifiable whole or partial prey in their stomachs

(Table 1, Supplementary Table 1). These prey taxa included stingarees (Urolophus sp.) (Fig.

2), eastern shovelnose rays (Aptychotrema rostrata), thornback cowfish (Lactoria fornasini), eastern smooth boxfish (Anoplocapros inermis), threebar porcupinefish (Dicotylichthys punctulatus), reef ocean perch (Helicolenus percoides) and a whiting (Sillago sp.). Notably, one $S$. mokarran stomach contained nine whole Urolophus sp., with a total stomach weight of $6.26 \mathrm{~kg}$, and a second S. mokarran stomach contained three whole Urolophus sp. and three whole A. rostrata $(6.15 \mathrm{~kg})$ (Fig. 2; Table 1). 
The stomach contents of seven of the Urolophus sp. and two of the A. rostrata rays predated by the two S. mokarran individuals were included in the metabarcoding analysis (Table 1). In contrast, none of the $C$. limbatus stomachs contained recognisable prey, and maximum stomach weights were generally much lighter (range $0.19-0.71 \mathrm{~kg}$ ) than those of $S$. mokarran $(0.38-6.26 \mathrm{~kg})($ Table 1$)$.

\section{Metabarcoding assays}

After quality filtering, 1,264,497 Mifish (12S) reads, 1,157,551 Crust16Sshort reads, and 237,745 Uni18S reads were retained for analyses (Supplementary Table 1). The PCR negative controls showed low levels of human contamination for the $18 \mathrm{~S}$ assay only (Table 1), whereas the control water sample collected alongside the C. limbatus stomach samples demonstrated contamination from Carcharhinidae DNA (most likely from C. limbatus). Carcharhinidae and/or Chondrichthyes reads were ubiquitous across all three genetic assays, including the Urolophus sp. and A. rostrata rays removed from the S. mokarran stomachs, and most likely represent the host predator's DNA.

Taxa identified in the $S$. mokarran metabarcoding assays included crustaceans, cartilaginous fish and teleosts. Crustaceans and teleosts were identified in the C. limbatus stomach contents (Table 1). In most cases, stomach-content analyses on the Urolophus sp. and A. rostrata removed from the $S$. mokarran stomachs displayed high taxon similarity to that of the apex predators' stomachs. For example, a comparison of 4H (S. mokarran) and 4SR (Urolophus sp.) revealed Gnathophis spp., Lepidotrigla spp., Pseudorhombus spp., and Anoplocapros spp. in common.

\section{Discussion}


The data collected here represent the first efforts at metabarcoding the stomach contents of $S$. mokarran and C. limbatus off eastern Australia. Our results support the general trends in the literature describing the diet of $S$. mokarran as being dominated by rays (Chapman and Gruber, 2002; Cliff, 1995; Strong et al., 1990), but also including teleosts and other sharks (Mourier et al., 2013; Roemer et al., 2016), and reports of C. limbatus predominantly feeding on teleosts (Barry et al., 2008; Tavares, 2008; Plumlee and Wells, 2016). By 'Russiandolling' (Varennes et al., 2014) the stomach contents of these marine apex- and mesopredators and their prey, we have also quantified some of the issues encountered when attempting to reconstruct trophic interactions from metabarcoding stomach contents. These two themes are discussed separately below.

Prior to considering the dietary preferences of the two species, it is important to acknowledge sampling constraints imposed by the selectivity characteristics of the fishing gear (Broadhurst et al., 2007). While some sharks are known to depredate catches from gillnets and might therefore be caught via attraction, in many cases animals are simply entangled as the move through the fished area. This is an important distinction from baited hook-and-line techniques, where captured animals are actively feeding. Such gear-specific catching mechanisms could explain the absence of larger prey items in some of the S. mokarran and all of the C. limbatus stomachs: these specimens might not have been foraging and certainly had not fed immediately prior to capture. An alternative hypothesis for the absence of whole prey in $C$. limbatus is that because these sharks were smaller, any ingested prey, which in turn would also be smaller, might be more rapidly digested than the relatively large Aptychotrema rostrata and Urolophus sp. consumed by S. mokarran (Wetherbee and Cortes, 2012). 
Irrespective of causes for the absence of whole prey in several sharks, clearly, some $S$. mokarran had recently fed in the general area (considering the regional abundances of some whole prey items) and so, of the two species, their dietary preferences were the most clearly discernible. Based on whole prey items, S. mokarran consumed Myliobatiformes and Rajiformes, but also teleosts including both slow- (Anoplocapros inermis) and fast-moving species (Sillago sp.). Observations of prey handling by S. mokarran are limited, however the species has been observed to use its laterally expanded head (cephalofoil) to immobilise prey on the ocean floor during both the pursuit of bottom-dwelling rays (Dasyatis americana) (Strong, 1990), and the post-capture manipulation of pelagic rays (Aetobatus narinari) (Chapman and Gruber, 2002). Most of the prey items of the $S$. mokarran individuals identified in our study were bottom-dwellers (e.g. Urolophus sp., A. rostrata and $H$. percoides), which supports the above mechanisms of prey-capture and/or -manipulation (e.g. Compagno, 1988; Johnsen and Teeter, 1985; Nakaya, 1995).

Unlike for S. mokarran, we found no whole fish in the digestive-tracts of the four $C$.

limbatus. Nevertheless, metabarcoding indicated the presence of large species including Platycephalus spp. Several platycephalids occur nearshore off northern NSW, especially eastern bluespotted flathead, (P. caeruleopunctatus up to $0.6 \mathrm{~m} \mathrm{TL})$ and, to a lesser extent, dusky flathead (P. fuscus up to $1.2 \mathrm{~m} \mathrm{TL}$ ). Large individuals of these species were unlikely to be prey of other animals in the stomachs of $C$. limbatus, but in the absence of whole specimens any conclusions based on the exact platycephalid species are speculative.

Other primary target species identified by metabarcoding in both $S$. mokarran and $C$. limbatus included Dexillus spp., probably tufted sole, Dexillus muelleri; the only known species from this genus, occurring off more tropical areas of Australia. This might imply 
these sampled sharks $(5 \mathrm{H}, 6 \mathrm{H}, 1 \mathrm{BT}$, and 4BT) moved southwards from a more northern, tropical foraging area (Raoult et al., 2020), or less likely that an as yet unidentifed species of Dexillus occurs in northern NSW waters. Five of the S. mokarran and two of the C. limbatus also had Anoplocapros spp. metabarcoding reads sequenced from their stomach contents, and we observed A. inermis scales in the stomach of one S. mokarran, suggesting some dietary overlap with $C$. limbatus. Indeed, A. inermis is the only species in this genus (of three total species, including $A$. amygdaloides and A. lenticularis) found off eastern Australia.

While some larger primary prey items of $S$. mokarran and to a lesser extent $C$. limbatus could be identified, it was difficult to ascribe predation sources to the smaller taxa, such as the sandy sprat, Hyperlophus vittatus or biddies Gerres sp. (likely silver biddy G. subfasciatus, although this species overlaps with at least two other congeners in northern NSW) detected in the $12 \mathrm{~S}$ assay. These species could either be primary prey of the sharks or secondary prey consumed by the platycephalids. The Russian-doll effect (Varennes et al., 2014) is exemplified well by comparing predator-prey stomach content metabarcoding reads (Table 1). For those S. mokarran that contained whole prey items (e.g. Myliobatiformes), DNA metabarcoding assays yielded close matches between predator and prey stomach contents. It is therefore difficult to conclude whether the S. mokkoran (less likely) or Urolophus sp. or Aptychotrema rostrata (most likely) were feeding on smaller prey items, such as decapod crustaceans and smaller fish species. It is likely that the chyme of both predator and (whole) prey cross-contaminated the other.

Similarly, our metabarcoding approach could not determine whether smaller sharks had been consumed by $S$. mokarran (as expected from the literature), due to the fact that all $S$. mokarran and their whole prey stomach samples included an abundance of $12 \mathrm{~S}$ 
322

323

324

325

Carcharhinidae reads. However, the $16 \mathrm{~S}$ assay did suggest these reads likely reflected the host predator's DNA, considering $S$. mokarran reads were identified both from S. mokarran and Urolophus sp. stomach contents, but at very low abundances. Blocking primers designed to exclude the host predator's DNA would be a worthwhile inclusion in future metabarcoding dietary studies (e.g. Leray et al., 2013, 2015; Takahashi et al., 2020), while shark-specific primers could also prove more informative on this topic (Taberlet et al., 2018). Alternatively, increasing the depth of sequencing may facilitate picking up the low template (prey) fraction of the metabarcoding chyme despite the presence of host DNA that would otherwise swamp the PCR amplification process.

In this study, metabarcoding assays provided some novel insights into the dietary preferences of $S$. mokarran and C. limbatus off eastern Australia. These species appear to have some dietary overlap, but with consistency among prey species identified in studies of their feeding ecology from across their broader ranges (Barry et al., 2008; Chapman and Gruber, 2002; Cliff, 1995; Mourier et al., 2013; Roemer et al., 2016; Strong et al., 1990; Tavares, 2008; Plumlee and Wells, 2016). Sphyrna mokkaran fed predominantly on Myliobatiformes and Rajiformes, but also teleosts, whereas $C$. limbatus fed predominantly on teleosts, which is consistent with its smaller body size and lack of cephalofoil that allows specialized feeding of benthic prey.

Nevertheless, the 'Russian-doll effect' made the reconstruction of trophic interactions from stomach metabarcoding data problematic. Extensive cross contamination in situ between predator-prey digestive tracts was evident, which also limited the ability to discriminate between first-order predators of smaller teleosts and crustacean taxa. The literature on the Russian-doll effect in metabarcoding dietary studies is limited (Varennes et al., 2014; 
347 reviewed in Clare, 2014; Nielsen et al., 2018) but certainly deserves further attention. We 348 suggest that while the approach offers some utility in identifying unseen taxa, confirmation 349 via visual identification and across sufficient replication (ideally from various sampling 350 methods) is still required to comprehensively understand diet preferences. 


\section{References}

352

Alberdi, A., Aizpurua, O., Bohmann, K., Gopalakrishnan, S., Lynggaard, C., Nielsen, M., Gilbert, M.T.P. (2019). Promises and pitfalls of using high-throughput sequencing for diet analysis. Molecular Ecology Resources, 19, 327-348.

Amundesen, P-A., Sánchez-Hernández, J. (2019). Feeding studies take guts—critical review and recommendations of methods for stomach contents analysis in fish. Journal of Fish Biology, 95, 1364-1373.

Barbato, M., Kovacs, T., Coleman, M., Broadhurst, M., de Bruyn, M. (2019). Metabarcoding of stomach-content analyses: Comparing tissue and ethanol preservative-derived DNA. Ecology and Evolution, 9(5), 2678-87.

Barry, K.P., Condrey, R.E., Driggers, W.B., Jones, C.M. (2008). Feeding ecology and growth of neonate and juvenile blacktip sharks Carcharhinus limbatus in the TimbalierTerrebone Bay complex, LA, U.S.A. Journal of Fish Biology, 73, 650-662.

Berry, O., Bulman, C., Bunce, M., Coghlan, M., Murray, D.C., Ward, R.D. (2015). Comparison of morphological and DNA metabarcoding analyses of diets in exploited marine fishes. Marine Ecology Progress Series, 540, 167-181.

Berry, T.E., Osterrieder, S.K., Murray, D.C., Coghlan, M.L., Richardson, A.J., Grealy, A.K., Stat, M., Bejder, L., Bunce, M. (2017). DNA metabarcoding for diet analysis and biodiversity: A case study using the endangered Australian sea lion (Neophoca cinerea). Ecology and Evolution, 7(14), 5435-5453.

Bessey, C., Jarman, S.N., Stat, M., Rohner, C., Bunce, M., Koziol, A., Power, M., Rambahiniarison, J.M., Ponzo, A., Richardson, A.J., Berry, O. (2019). DNA metabarcoding assays reveal a diverse prey assemblage for Mobula rays in the Bohol Sea, Philippines. Ecology and Evolution, 9(5), 2459-2474. 
Bizzarro, J.J., Carlisle, A.B., Smith, W.D., Cortés, E. (2017). Diet composition and trophic ecology of Northeast Pacific Ocean sharks. Advances in Marine Biology, 77, 111148.

Braccini, M., Van Rijn, J., Frick, L. (2012). High post-capture survival for sharks, rays and chimaeras discarded in the main shark fishery of Australia? PLoS One, 7, 1-9 e32547.

Broadhurst, M.K., Kennelly, S.J., Gray, C.A. (2007). Strategies for improving the selectivity of fishing gears. In: Kennelly, S.J. (ed.), By-catch Reduction in the World's Fisheries, pp. 1-18, Springer-Verlag Inc, Dordrecht, The Netherlands.

Broadhurst, M.K., Cullis, B.R. (2020). Mitigating the discard mortality of non-target, threatened elasmobranchs in bather-protection gillnets. Fisheries Research, 222, 105435.

Chapman, D.D., Gruber, S.H. (2002). A further observation of the prey-handling behavior of the great hammerhead shark, Sphyrna mokarran: Predation upon the spotted eagle ray, Aetobatus narinari. Bulletin of Marine Science, 70, 947-952.

Clare, E.L. (2014). Molecular detection of trophic interactions: emerging trends, distinct advantages, significant considerations and conservation applications. Evolutionary Applications, 7, 1144-1157.

Clarke, L.J., Trebilco, R., Walters, A., Polanowski, A.M., Deagle, B.E. (2020). DNA-based diet analysis of mesopelagic fish from the southern Kerguelen Axis. Deep Sea Research Part II: Topical Studies in Oceanography, 174, 104494.

Cliff, G. (1995). Sharks caught in the protective gill nets off KwaZulu-Natal, South Africa. 8. The great hammerhead shark Sphyrna mokarran (Rüppell). South African Journal of Marine Science, 15, 105-114.

Compagno, L.J.V. (1988). Sharks of the Order Carcharhiniformes. USA: Princeton University Press. 
400

401

402

403

404

405

406

407

408

409

410

411

412

413

414

415

416

417

418

419

420

421

422

423

424

Deagle, B.E., Thomas, A.C., McInnes, J.C., Clarke, L.J., Vesterinen, E.J., Clare, E.L., Kartzinel, T.R., Eveson, J.P. (2019). Counting with DNA in metabarcoding studies: How should we convert sequence reads to dietary data? Molecular Ecology, 28, 391406.

Diaz, S., Settele, J., Brondizio, E.S., Ngo, H.T., Agard, J., Arneth, A., Balvanera, P., Brauman, K.A., Butchart, S.H.M., Chan, K.M.A., Garibaldi, L.A., Ichii, J., Subramanian, S.M., Midgley, G.F., Miloslavich, P., Molnar, Z., Obura, D., Pfaff, A., Polasky, S., Purvis, A., Razzaque, J., Reyers, B., Chowdhury, R.R., Shin, Y-J., Visseren-Hamakers, I., Willis, K.J., Zayas, C.N. (2020). Pervasive human-driven decline of life on Earth points to the need for transformative change. Science, 366, $\operatorname{eaax} 3100$.

Dulvy, N.K., Fowler, S.L., Musick, J.A., Cavanagh, R.D., Kyne, P.M., Harrison, L.R., Carlson, J.K., Davidson, L.N.K., Fordham, S.V., Francis, M.P., Pollock, C.M., Simpfendorfer, C.A., Burgess, G.H., Carpenter, K.E., Compagno, L.J.V., Ebert, D.A., Gibson, C., Heupel, M.R., Livingstone, S.R., Sanciagno, J.C., Stevens, J.D., Valenti, S., White, W.T. (2014). Extinction risk and conservation of the world's sharks and rays. eLife, 3, e00590.

Edgar, R.C. (2010). Search and clustering orders of magnitude faster than BLAST. Bioinformatics, 26(19), 2460-2461.

Frøslev, T.G., Kjøller, R., Bruun, H.H., Ejrnæs, R., Brunbjerg, A.K., Pietroni, C., Hansen, A.J. (2017). Algorithm for post-clustering curation of DNA amplicon data yields reliable biodiversity estimates. Nature Communications, 8(1), 1-11.

Gallagher, A.J., Klimley, A.P. (2018). The biology and conservation status of the large hammerhead shark complex: the great, scalloped and smooth hammerheads. Reviews in Fish Biology and Fisheries, 28, 777-794. 
Heithaus, M.R., Frid, A., Wiesing, A.J., Worm, B (2008). Predicting ecological consequences of marine top predator declines. Trends in Ecology and Evolution, 23, 202-210.

Heupel, M.R., Knip, D.M., Simpfendorfer, C.A., Dulvy, N.K. (2014). Sizing up the ecological role of sharks as predators. Marine Ecology Progress Series, 495, 291-298.

IUCN 2018. The IUCN Red List of Threatened Species. Version 2018-1. $<\mathrm{http}: / /$ www.iucnredlist.org $>$. Downloaded on 20 January 2021.

Johnsen, P.B., Teeter, J.H. (1985). Behavioral responses of the bonnethead shark (Sphyrna tiburo) to controlled olfactory stimulation. Marine Behavioural Physiology, 11, 283291.

Jones, K.R., Klein, C.J., Grantham, H.S., Possingham, H.P., Halpern, B.S., Burgess, N.D., Butchart, S.H.M., Robinson, J.G., Kingston, N., Bhola, N., Watson, J.E.M. (2020). Area requirements to safeguard Earth's marine species. One Earth, 2, 188-196.

Leigh, S.C., Papastamatiou, Y., German, D.P. (2017). The nutritional physiology of sharks. Reviews in Fish Biology and Fisheries, 27, 561-585.

Leray, M., Agudelo, N., Mills, S.C., Meyer, C.P. (2013). Effectiveness of annealing blocking primers versus restriction enzymes for characterization of generalist diets: unexpected prey revealed in the gut contents of two coral reef fish species. PloS One, 8(4), e58076.

Leray, M., Meyer, C.P., Mills, S.C. (2015). Metabarcoding dietary analysis of coral dwelling predatory fish demonstrates the minor contribution of coral mutualists to their highly partitioned, generalist diet. PeerJ, 3, e1047.

Miya, M., Sato, Y., Fukunaga, T., Sado, T., Poulsen, J.Y., Sato, K., Minamoto, T., Yamamoto, S., Yamanaka, H., Araki, H., Kondoh, M., Iwasaki, W. (2015). MiFish, a set of universal PCR primers for metabarcoding environmental DNA from fishes: detection of more than 230 subtropical marine species. Royal Society Open Science, 2(7), 150088 . 
Mourier, J., Planes, S., Buray, N. (2013). Trophic interactions at the top of the coral reef food chain. Coral Reefs, 32, 285-285.

Mousavi-Derazmahalleh, M., Stott, A., Lines, R., Peverley, G., Nester, G., Simpson, T., Zawierta, M., De La Pierre, M., Bunce, M., Christophersen, C. (2020). eDNAFlow, an automated, reproducible and scalable workflow for analysis of environmental DNA (eDNA) sequences exploiting Nextflow and Singularity. Molecular Ecology Resources, In Press.

Nakaya, K. (1995). Hydrodynamic function of the head in the hammerhead sharks (Elasmobranchii: Sphyrinidae). Copeia, 2, 330-336.

Nielsen, J.M., Clare, E.L., Hayden, B., Brett, M.T., Kratina, P. (2018). Diet tracing in ecology: Method comparison and selection. Methods in Ecology and Evolution, 9, $278-291$.

Plumlee, JD., Wells, R. J.D. (2016). Feeding ecology of three coastal shark species in the northwest Gulf of Mexico. Marine Ecology Progress Series, 550, 163-174.

Pompanon, F., Deagle, B.E., Symondson, W.O.C., Brown, D.S., Jarman, S.N., Taberlet, P. (2012). Who is eating what: diet assessment using next generation sequencing. Molecular Ecology, 21, 1931-1950.

Raoult V., Broadhurst, M.K., Peddemors, V.M., Williamson, J.E., Gaston, T.F. (2019). Resource use of great hammerhead sharks (Sphyrna mokarran) off eastern Australia. Journal of Fish Biology, 95, 1430-1440.

Raoult V., Trueman, C.N., Kingsbury, K.M., Gillanders, B.M., Broadhurst, M.K., Williamson, J.E., Nagelkerken, I., Booth, D.J., Peddemors, V.M., Couturier, L.I.E., Gaston, T.F. (2020). Predicting geographic ranges of marine animal populations using stable isotopes: a case study of great hammerhead sharks in eastern Australia. Frontiers in Marine Science, 7, 594636. 
Roemer, R.P., Gallagher, A.J., Hammerschlag, N. (2016). Shallow water tidal flat use and associated specialized foraging behavior of the great hammerhead shark (Sphyrna mokarran). Marine and Freshwater Behaviour and Physiology, 49, 235-249.

Roff, G., Doropoulos, C., Rogers, A., Bozec, Y.M., Krueck, N.C., Aurellado, E., Priest, M., Birrell, C., Mumby, P.J. (2016). The ecological role of sharks on coral reefs. Trends in Ecology and Evolution, 31(5), 395-407.

Roff, G., Brown, C.J., Priest, M.A. Mumby, P.J. (2018). Decline of coastal apex shark populations over the past half century. Communications Biology, 1, 223.

Stevens, J.D., Wayte, S.E. (2009). Case study: the bycatch of pelagic sharks in Australia's tuna longline fisheries. In: M.D. Camhi, E.K. Pikitch, \& E.A. Babcock (Eds.), Sharks of the Open Ocean; Biology, Fisheries and Conservation (pp. 260-267). UK: Blackwell Publishing.

Strong, W.R., Snelson, F.F., Gruber, S.H. (1990) Hammerhead shark predation on stingrays: an observation of prey handling on Sphyrna mokarran. Copeia, 3, 836-840.

Sousa, L.L., Xavier, R., Costa, V., Humphries, N.E., Trueman, C., Rosa, R., Sims, D.W., Queiroz, N. (2016). DNA barcoding identifies a cosmopolitan diet in the ocean sunfish. Scientific Reports, 6, 28762.

Sumpton, W.D., Taylor, S.M., Gribble, N.A., McPherson, G., Ham, T. (2011). Gear selectivity of large-mesh nets and drumlines used to catch sharks in the Queensland shark control program. African Journal of Marine Science, 33, 37-43.

Taberlet, P., Bonin A., Zinger L., Coissac E. (2018). Environmental DNA for Biodiversity Research and Monitoring. UK: Oxford University Press.

Takahashi, M., DiBattista, J.D., Jarman, S., Newman, S.J., Wakefield, C.B., Harvey, E.S., Bunce, M. (2020). Partitioning of diet between species and life history stages of 
sympatric and cryptic snappers (Lutjanidae) based on DNA metabarcoding. Scientific Reports, 10(1), 1-13.

501

Tavares, R. (2008). Occurrence, diet and growth of juvenile blacktip sharks, Carcharhinus limbatus, from Los Roques Archipelago National Park, Venezuela. Caribbean Journal of Science, 44, 291-302.

Varennes, Y-D., Boyer, S., Wratten, S.D. (2014). Un-nesting DNA Russian dolls - the potential for constructing food webs using residual DNA in empty aphid mummies. Molecular Ecology, 23, 3925-3933.

Walker, T.I., Hudson, R.J., Gason, A.S. (2005). Catch evaluation of target, by-product and by-catch species taken by gillnets and longlines in the shark fishery of south-eastern Australia. Journal of Northwest Atlantic Fishery Science, 35, 505-530.

Wetherbee, B.M., Cortés, E., Bizzarro, J.J. (2012). Food consumption and feeding habits. In: J.C. Carrier, J.A. Musick, M.R. Heithaus (Eds.), Biology of Sharks and their Relatives (pp 239-264). USA: CRC Press.

Yoon, T-H., Kang, H-E., Lee, S. R., Lee, J-B., Baeck, G.W., Park, H., Kim, H-W. (2017). Metabarcoding analysis of the stomach contents of the Antarctic Toothfish (Dissostichus mawsoni) collected in the Antarctic Ocean. PeerJ, 5, e3977.

Young, J.W., Hunt, B.P.V., Cook, T.R., Llopiz, J.K., Hazen, E.L., Pethybridge, H.R., Ceccarelli, D., Lorrain, A., Olson, R.J., Allain, V., Menkes, C., Patterson, T., Nicol, S., Lehodey, P., Kloser, R.J., Arrizabalaga, H., Choy, C.A. (2015). The trophodynamics of marine top predators: Current knowledge, recent advances and challenges. Deep Sea Research Part II: Topical Studies in Oceanography, 113, 170187.

Zhan, A., Hulak, M., Sylvester, F., Huang, X., Adebayo, A.A., Abbott, C.L., Adamowicz, S.J., Heath, D.D., Cristescu, M.E., MacIsaac, H.J. (2013). High sensitivity of 454 
526

527 Data Archiving Statement: The datasets generated and analysed during the current study will be archived in Dryad

529

530

\section{Acknowledgments}

531 The authors would like to acknowledge Mahsa Mousavi Mousaviderazmahalleh for

532 bioinformatic assistance. MdB acknowledges start-up funds from The University of Sydney and the USyd School of Life and Environmental Sciences. MKB acknowledges funding from

534 NSW DPI. Thanks are extended to the crew of the FV 'Pluka' and Sean Blake, Isabelle

535 Thiebaud and Dylon Grogan for helping to collect the data. This work was also supported by 536 resources provided by the Pawsey Supercomputing Centre with funding from the Australian 537 Government and the Government of Western Australia.

538

\section{Author Contributions}

540 M.K.B. and M.B. collected the samples. M.B., M.K.B., and M.d.B. designed and conducted 541 the experiments. J.D.D. analyzed the metabarcoding data. M.d.B. and M.K.B. wrote the 542 paper. All authors contributed intellectually to the interpretation of the results and writing of 543 the manuscript. 
closest taxonomic level) and through visual inspection. Prey items identified by metabarcoding assays are listed for each of two filtering stringencies per amplicon (see Methods). Values in parentheses after species designation show the number of reads observed for that taxon (values listed in red reflect $\leq 10$ reads; ' $n / a$ ' indicates that the sample was not sequenced, while ' 0 ' indicates no amplification of relevant taxa). Species IDs shown in bold are those taxa

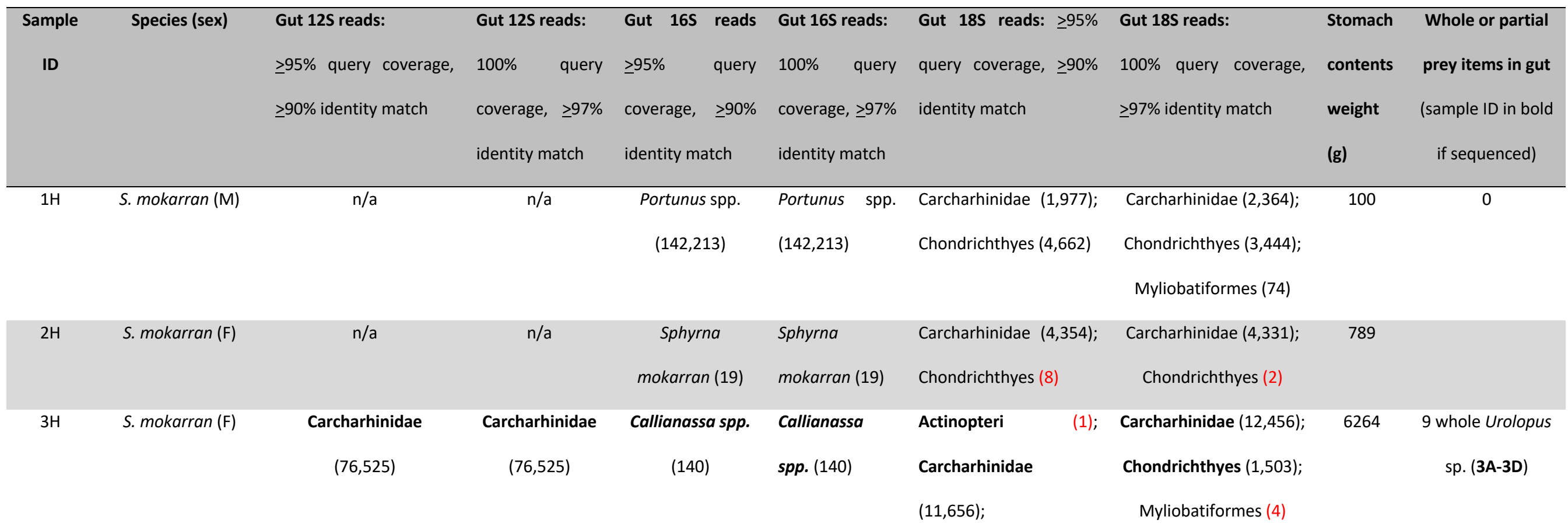

Chondrichthyes $(2,738)$ 


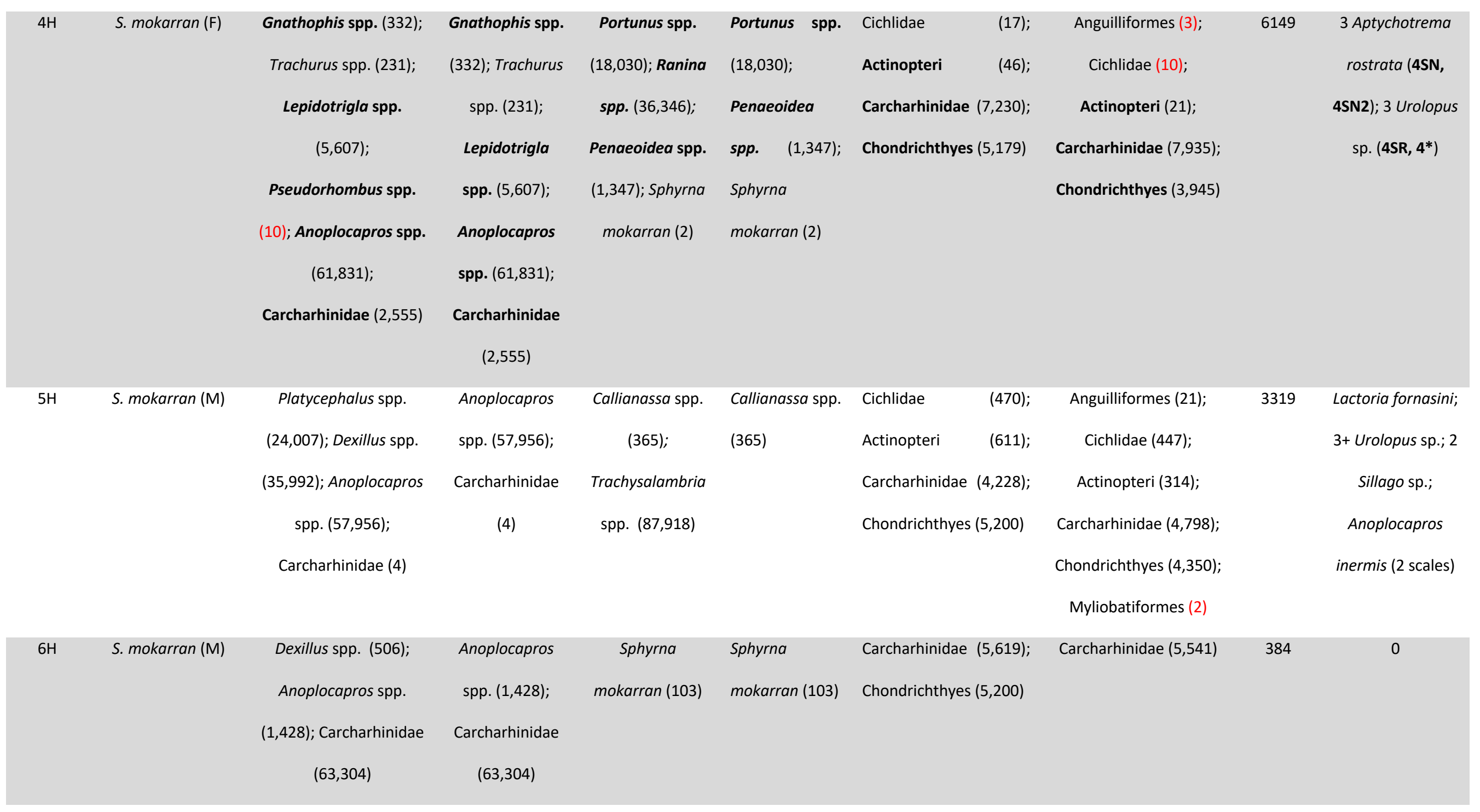


spp. $(2,318)$;

Diodontidae

Diodontidae $(35,675)$

$(35,675)$;

Monocentris spp.

Monocentris

$(2,740)$; Carcharhinidae spp. $(2,740)$;

Carcharhinidae $(4,188) ; \quad$ Chondrichthyes (239);

Urolopus sp.

\section{Chondrichthyes (402) Myliobatiformes (12)}

(7SR);

$1+$ Dicotylichthys punctulatus

(jawbone)

\section{$(4,016) \quad$ Carcharhinidae}

$(4,016)$

\begin{tabular}{|c|c|c|c|c|c|c|c|c|c|}
\hline $\mathrm{CH}$ & $\begin{array}{c}\text { Sample control -S. } \\
\text { mokarran }\end{array}$ & 0 & 0 & 0 & 0 & 0 & 0 & $\mathrm{n} / \mathrm{a}$ & $\mathrm{n} / \mathrm{a}$ \\
\hline PCRneg1 & PCR negative 1 & 0 & 0 & 0 & 0 & Homo sapiens $(8,126)$ & Homo sapiens $(8,126)$ & $\mathrm{n} / \mathrm{a}$ & $\mathrm{n} / \mathrm{a}$ \\
\hline 1BT & C. limbatus (M) & $\begin{array}{c}\text { Hyperlophus vittatus } \\
(19,547) ; \text { Gerres spp. } \\
(25,466) ; \text { Dexillus spp. } \\
(378) \text {; Anoplocapros } \\
\text { spp. (933); } \\
\text { Carcharhinidae (72); }\end{array}$ & $\begin{array}{c}\text { Hyperlophus } \\
\text { vittatus } \\
\text { (19,547); } \\
\text { Anoplocapros } \\
\text { spp. (933); } \\
\text { Carcharhinidae } \\
\text { (72) }\end{array}$ & $\begin{array}{l}\text { Carcharhinidae } \\
\qquad(16)\end{array}$ & $\begin{array}{l}\text { Carcharhinidae } \\
\text { (16) }\end{array}$ & $\begin{array}{l}\text { Cichlidae (19); } \\
\text { Actinopteri } \\
\text { Carcharhinidae }(1,739) ; \\
\text { Chondrichthyes (5) }\end{array}$ & $\begin{array}{l}\text { Actinopteri (25); } \\
\text { Carcharhinidae (1); } \\
\text { Chondrichthyes (4) }\end{array}$ & 708 & 0 \\
\hline
\end{tabular}




\begin{tabular}{|c|c|c|c|c|c|c|c|c|c|}
\hline & & & & $\begin{array}{l}\text { Carcharhinidae } \\
\qquad(30)\end{array}$ & $\begin{array}{l}\text { Carcharhinidae } \\
\text { (30) }\end{array}$ & & & & \\
\hline 3BT & C. limbatus (M) & Carcharhinidae $(10,460)$ & $\begin{array}{l}\text { Carcharhinidae } \\
\qquad(10,460)\end{array}$ & 0 & 0 & $\begin{array}{l}\text { Carcharhinidae }(6,201) \text {; } \\
\text { Chondrichthyes (9) }\end{array}$ & $\begin{array}{l}\text { Carcharhinidae (591); } \\
\text { Chondrichthyes (1) }\end{array}$ & 195 & 0 \\
\hline 4BT & C. limbatus (F) & $\begin{array}{c}\text { Platycephalus spp. } \\
(1,636) ; \text { Dexillus spp. } \\
\text { (2,011); Anoplocapros } \\
\text { spp. }(4,461) ; \\
\text { Carcharhinidae }(24,679)\end{array}$ & $\begin{array}{l}\text { Anoplocapros } \\
\text { spp. }(4,461) \text {; } \\
\text { Carcharhinidae } \\
\text { (24,679) }\end{array}$ & Lucilia spp. (2) & Lucilia spp. (2) & $\begin{array}{l}\text { Carcharhinidae }(4,008) \text {; } \\
\text { Chondrichthyes (9) }\end{array}$ & 0 & 297 & 0 \\
\hline CBT & $\begin{array}{c}\text { Sample Control }-C \text {. } \\
\text { limbatus }\end{array}$ & Carcharhinidae $(1,145)$ & $\begin{array}{l}\text { Carcharhinidae } \\
\qquad(1,145)\end{array}$ & 0 & 0 & Homo sapiens (575) & Homo sapiens (575) & $\mathrm{n} / \mathrm{a}$ & $\mathrm{n} / \mathrm{a}$ \\
\hline PCRneg2 & PCR negative 2 & 0 & 0 & 0 & 0 & Homo sapiens $(1,679)$ & Homo sapiens $(1,679)$ & $\mathrm{n} / \mathrm{a}$ & $\mathrm{n} / \mathrm{a}$ \\
\hline $3 \mathrm{~A}$ & Urolopus sp. & $\begin{array}{c}\text { Homo sapiens }(3) \text {; } \\
\text { Carcharhinidae }(4,643)\end{array}$ & $\begin{array}{l}\text { Homo sapiens } \\
\qquad(3) ; \\
\text { Carcharhinidae } \\
\text { (4,643) }\end{array}$ & 0 & 0 & Chondrichthyes $(9,489)$ & $\begin{array}{l}\text { Carcharhinidae }(11) \text {; } \\
\text { Chondrichthyes }(9,476)\end{array}$ & unknown & 0 \\
\hline $3 B$ & Urolopus sp. & $\begin{array}{l}\text { Carcharhinidae } \\
\qquad(18,590)\end{array}$ & $\begin{array}{l}\text { Carcharhinidae } \\
\qquad(18,590)\end{array}$ & $\begin{array}{l}\text { Callianassa spp. } \\
\qquad(143,578) ; \\
\text { Matuta spp. (71) }\end{array}$ & $\begin{array}{l}\text { Callianassa } \\
\text { spp. }(143,578)\end{array}$ & $\begin{array}{ll}\text { Callianassidae } & (10) ; \\
\text { Actinopteri } & (1) ; \\
\text { Carcharhinidae } & (43) ; \\
\text { Chondrichthyes } & (7,934)\end{array}$ & $\begin{array}{l}\text { Callianassidae (10); } \\
\text { Carcharhinidae (128); } \\
\text { Chondrichthyes }(7,857)\end{array}$ & unknown & 0 \\
\hline
\end{tabular}




\begin{tabular}{|c|c|c|c|c|c|c|c|c|c|}
\hline $3 C$ & Urolopus sp. & Carcharhinidae $(5,135)$ & $\begin{array}{c}\text { Carcharhinidae } \\
\qquad(5,135)\end{array}$ & $\begin{array}{l}\text { Callianassa spp. } \\
\qquad(66,115)\end{array}$ & $\begin{array}{l}\text { Callianassa } \\
\text { spp. }(66,115)\end{array}$ & 0 & 0 & unknown & 0 \\
\hline $3 \mathrm{D}$ & Urolopus sp. & Carcharhinidae $(3,923)$ & $\begin{array}{c}\text { Carcharhinidae } \\
\qquad(3,923)\end{array}$ & 0 & 0 & $\begin{array}{l}\text { Actinopteri }(3) ; \\
\text { Carcharhinidae }(3,208) ; \\
\text { Chondrichthyes } \\
(14,433)\end{array}$ & $\begin{array}{l}\text { Carcharhinidae }(40) \text {; } \\
\text { Chondrichthyes }(14,403)\end{array}$ & unknown & 0 \\
\hline $4 S R$ & Urolopus sp. & $\begin{array}{l}\text { Gnathophis spp. (69); } \\
\text { Lepidotrigla spp. (958); } \\
\text { Pseudorhombus spp. } \\
\text { (50); Anoplocapros spp. } \\
(29,358) \text {; Rhinobatidae } \\
(2) \text {; Carcharhinidae } \\
(41,434)\end{array}$ & $\begin{array}{l}\text { Gnathophis spp. } \\
\qquad(69) ; \\
\text { Lepidotrigla } \\
\text { spp. (958); } \\
\text { Anoplocapros } \\
\text { spp. }(29,358) \text {; } \\
\text { Carcharhinidae } \\
(41,434)\end{array}$ & $\begin{array}{c}\text { Sphyrna } \\
\text { mokarran (2) }\end{array}$ & $\begin{array}{l}\text { Sphyrna } \\
\text { mokarran (2) }\end{array}$ & $\begin{array}{l}\text { Actinopteri } \\
\text { Carcharhinidae }(3,208) ; \\
\text { Chondrichthyes }(9,806)\end{array}$ & $\begin{array}{l}\text { Carcharhinidae }(5,506) \text {; } \\
\text { Chondrichthyes }(7,071)\end{array}$ & unknown & 0 \\
\hline $4 \mathrm{SN}$ & $\begin{array}{c}\text { Aptychotrema } \\
\text { rostrata }\end{array}$ & $\begin{array}{l}\text { Lepidotrigla spp. (11); } \\
\text { Pseudorhombus spp. } \\
\text { (57,577); Anoplocapros } \\
\text { spp. (6,329); } \\
\text { Rhinobatidae (9,815); }\end{array}$ & $\begin{array}{c}\text { Lepidotrigla } \\
\text { spp. (11); } \\
\text { Anoplocapros } \\
\text { spp. (6,329); } \\
\text { Carcharhinidae }\end{array}$ & $\begin{array}{l}\text { Portunus spp. } \\
(67,051) ; \text { Ranina } \\
\text { spp. }(18,815)\end{array}$ & $\begin{array}{l}\text { Portunus spp. } \\
(67,051)\end{array}$ & $\begin{array}{ll}\text { Decapoda } & (3) ; \\
\text { Actinopteri } & (3) ; \\
\text { Carcharhinidae } & (74) ; \\
\text { Chondrichthyes } & \\
(16,656) & \end{array}$ & $\begin{array}{c}\text { Decapoda (3); } \\
\text { Actinopteri (3); } \\
\text { Carcharhinidae }(230) ; \\
\text { Chondrichthyes }(16,462)\end{array}$ & unknown & 0 \\
\hline
\end{tabular}




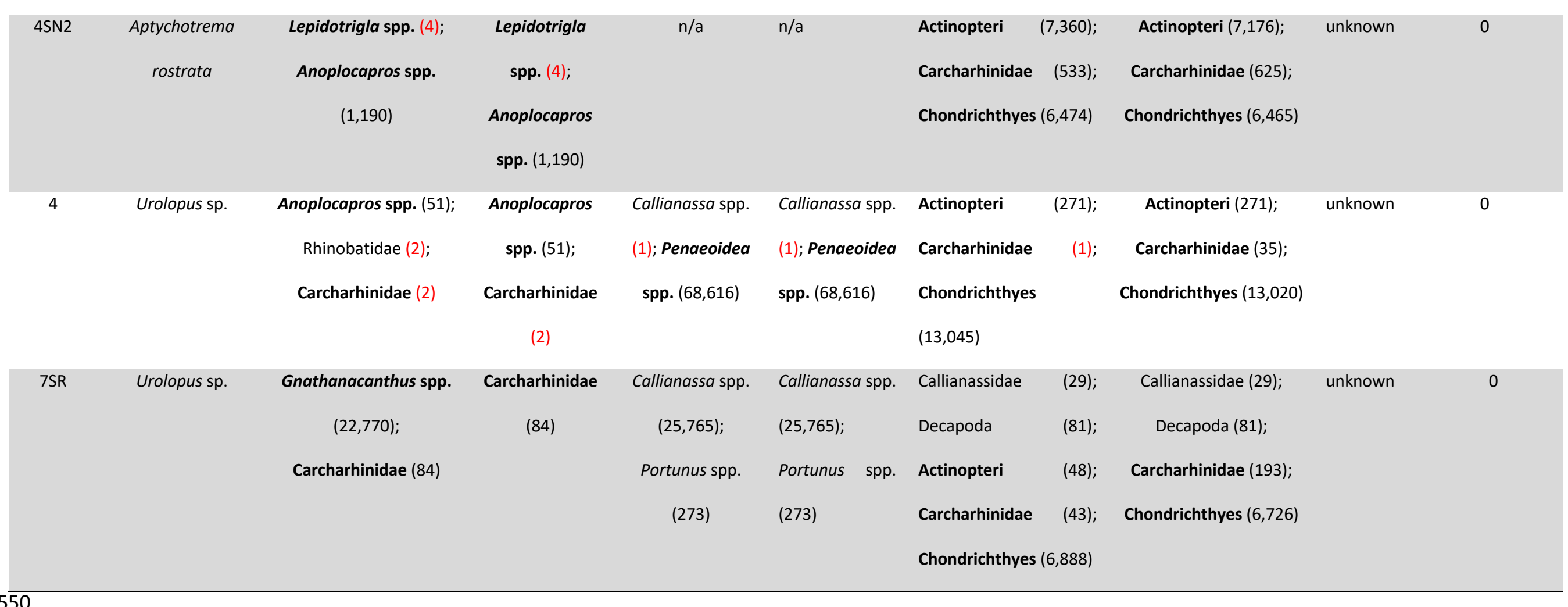


552 Figure 1. Location of bather-protection gillnets deployed off (a) Ballina and (b) Evans Head

553 in New South Wales, Australia from which sharks were sampled between 7 February and 13

554 March, 2018.

555

(a) Ballina
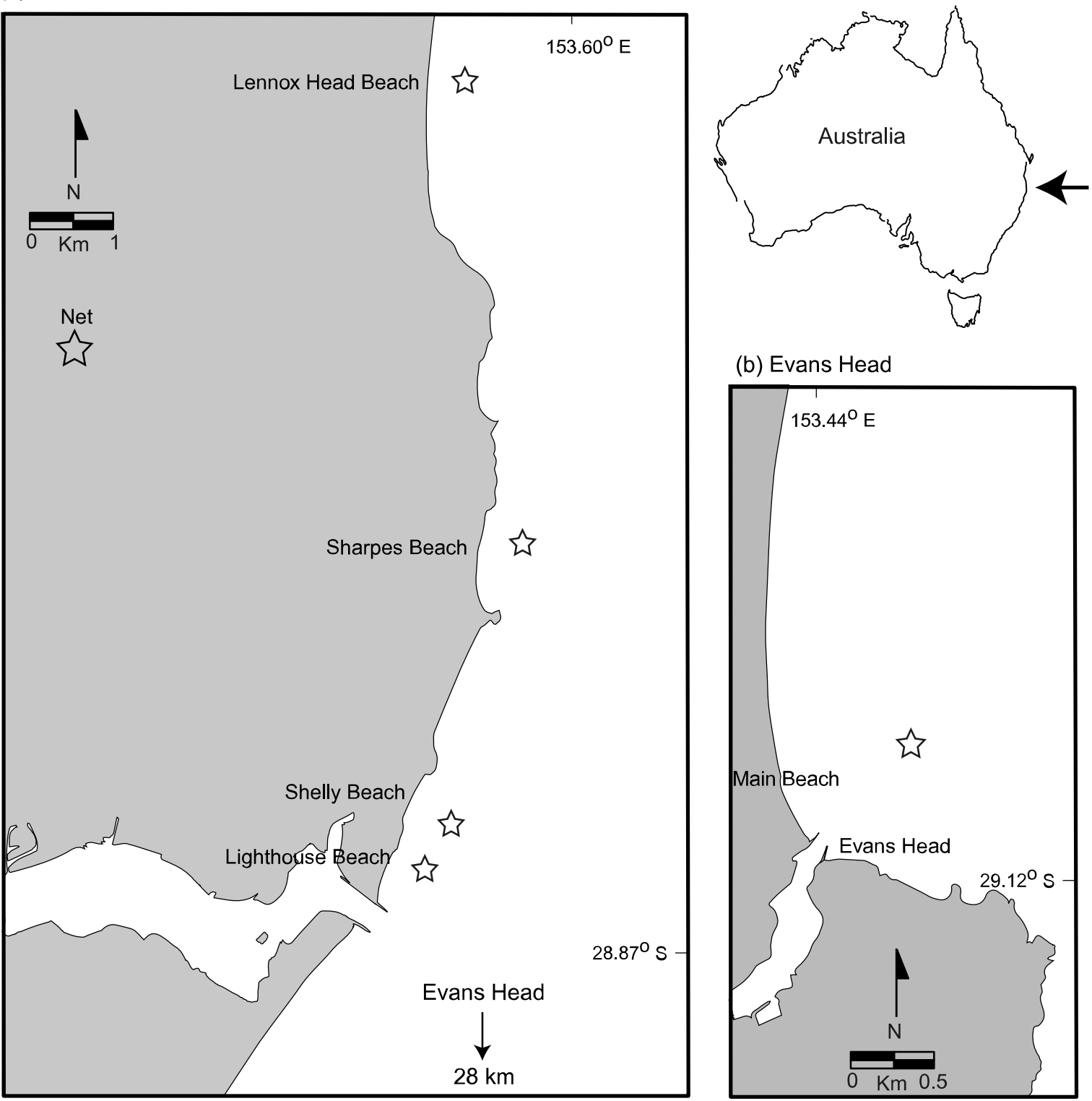

(b) Evans Head




558 Figure 2. Photos of (a) jaw bones and (b) Urolophus sp. in the stomachs of two Sphyrna 559 mokarran.

(a)

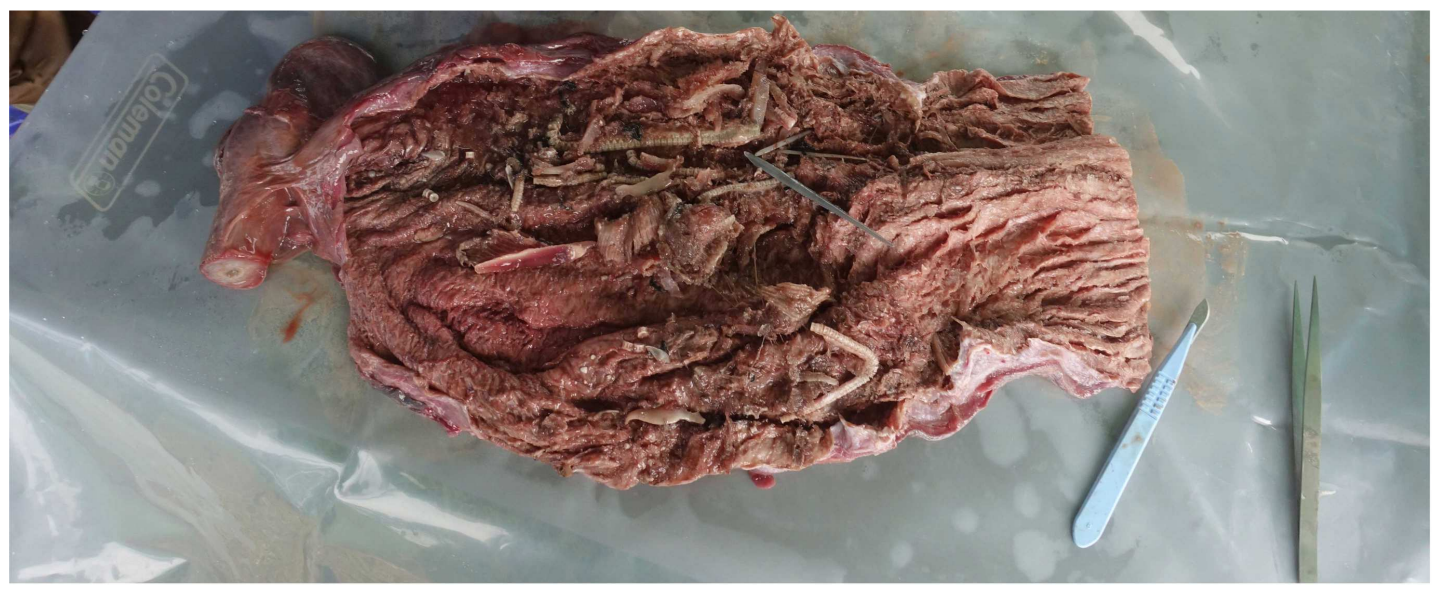

(b)

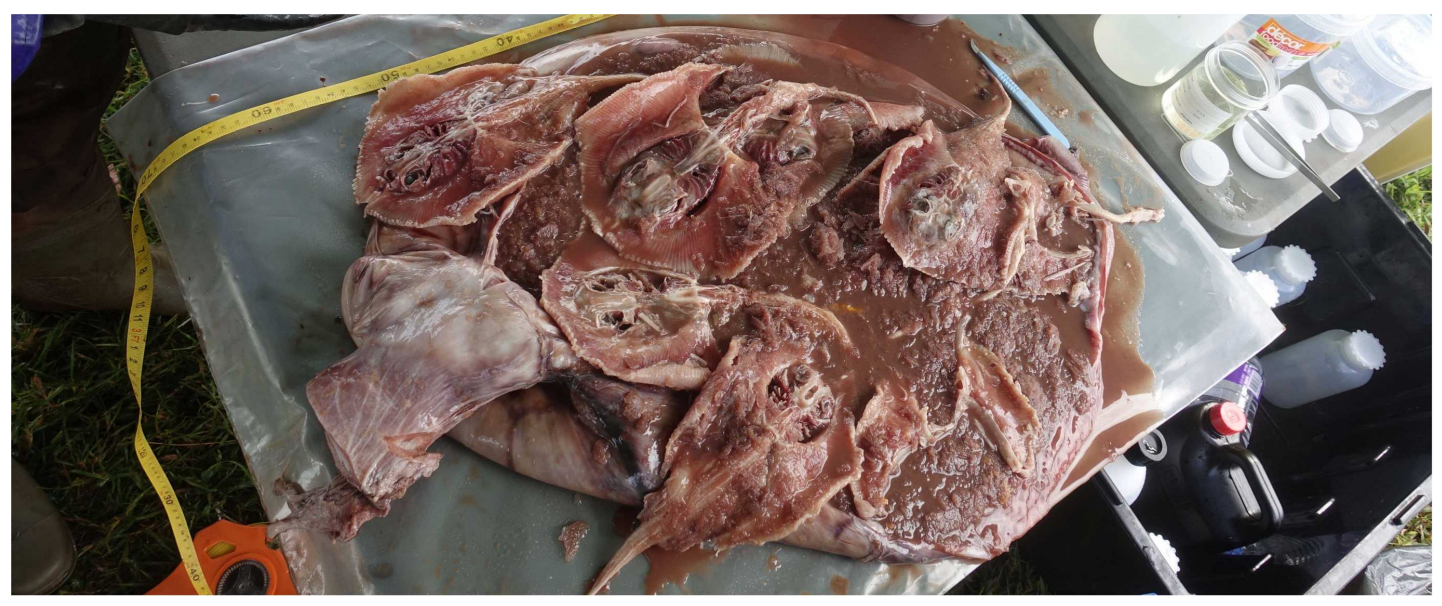


Figures

(a) Ballina
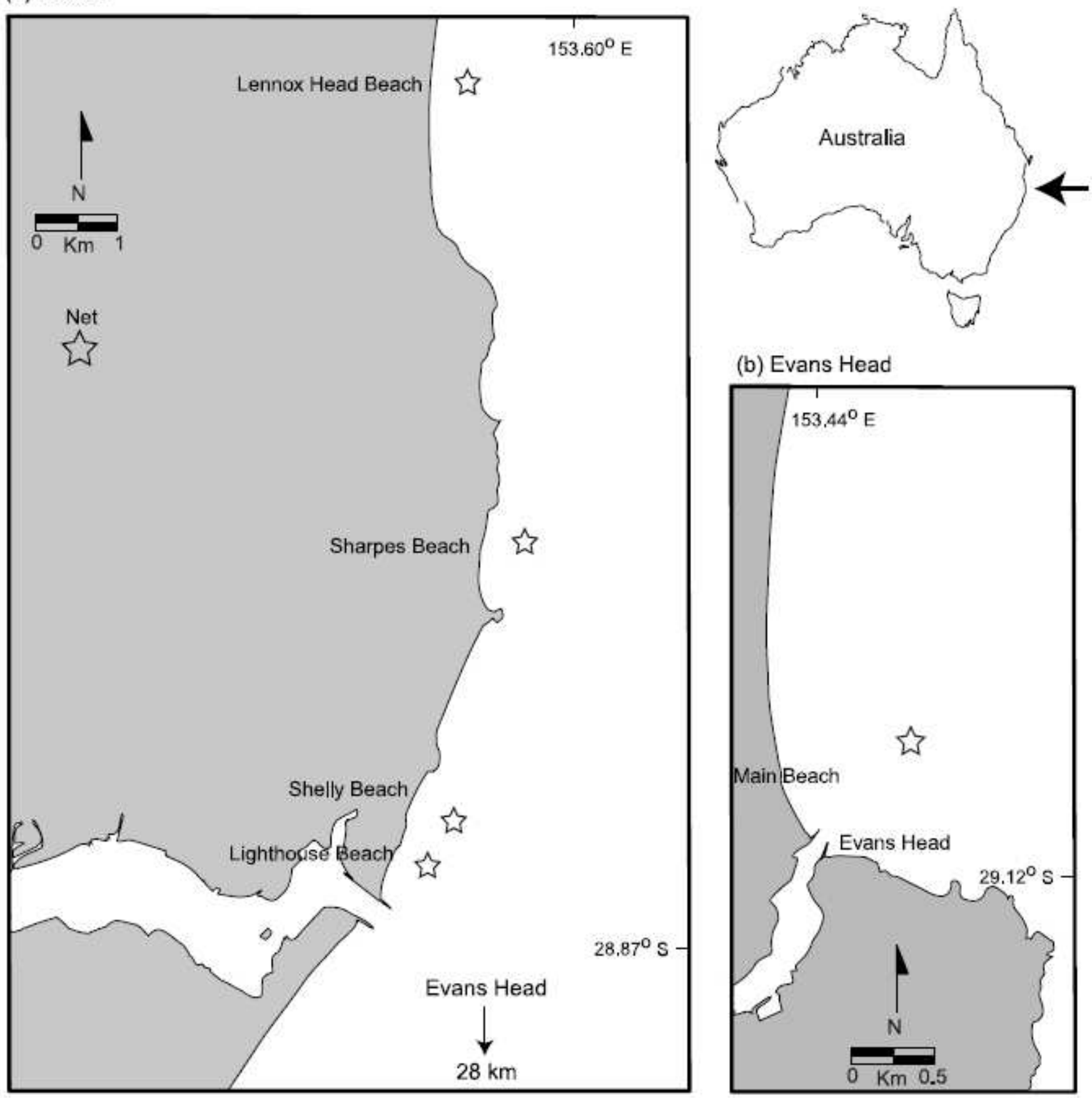

(b) Evans Head

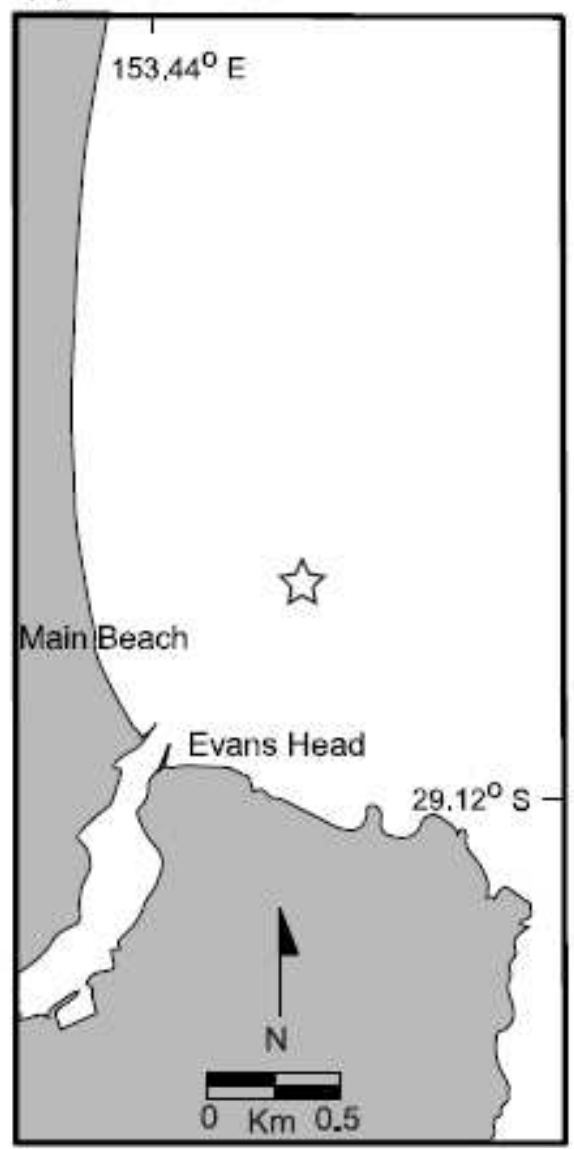

Figure 1

Location of bather-protection gillnets deployed off (a) Ballina and (b) Evans Head in New South Wales, Australia from which sharks were sampled between 7 February and 13 March, 2018. Note: The designations employed and the presentation of the material on this map do not imply the expression of any opinion whatsoever on the part of Research Square concerning the legal status of any country, 
territory, city or area or of its authorities, or concerning the delimitation of its frontiers or boundaries. This map has been provided by the authors.

(a)

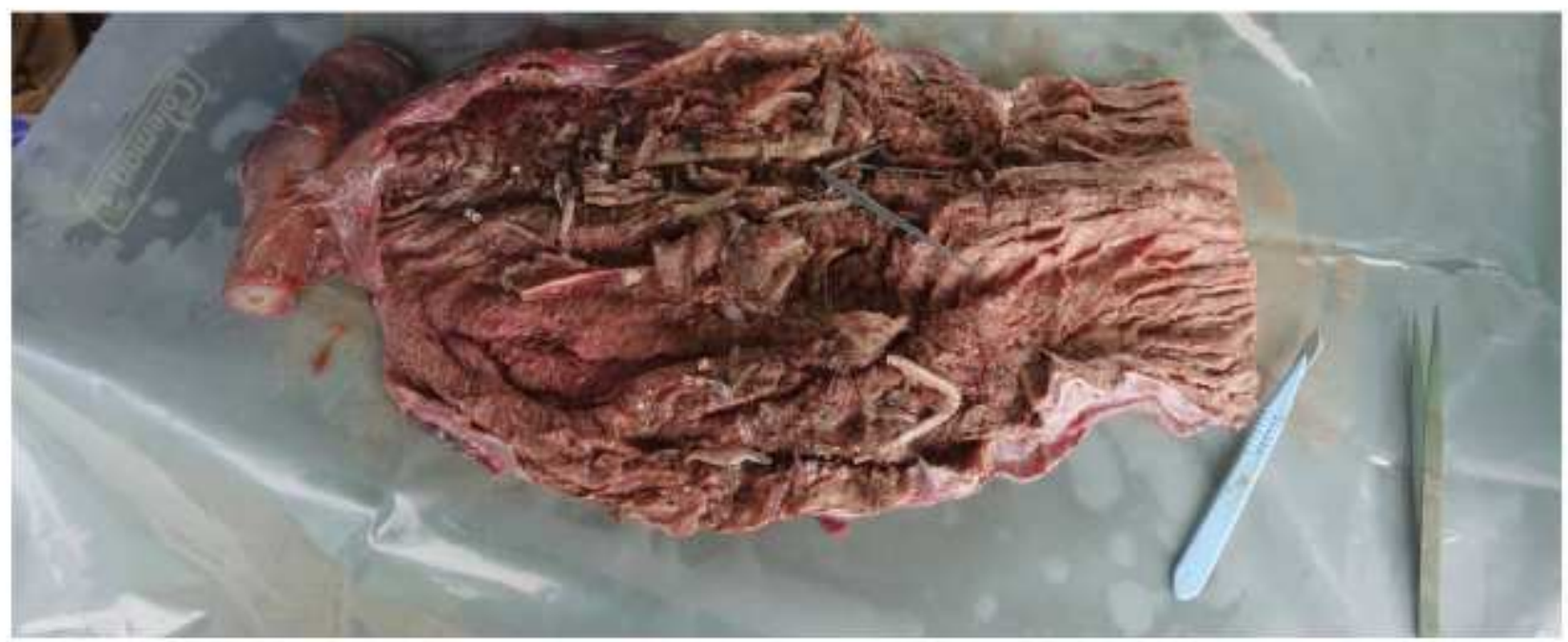

(b)

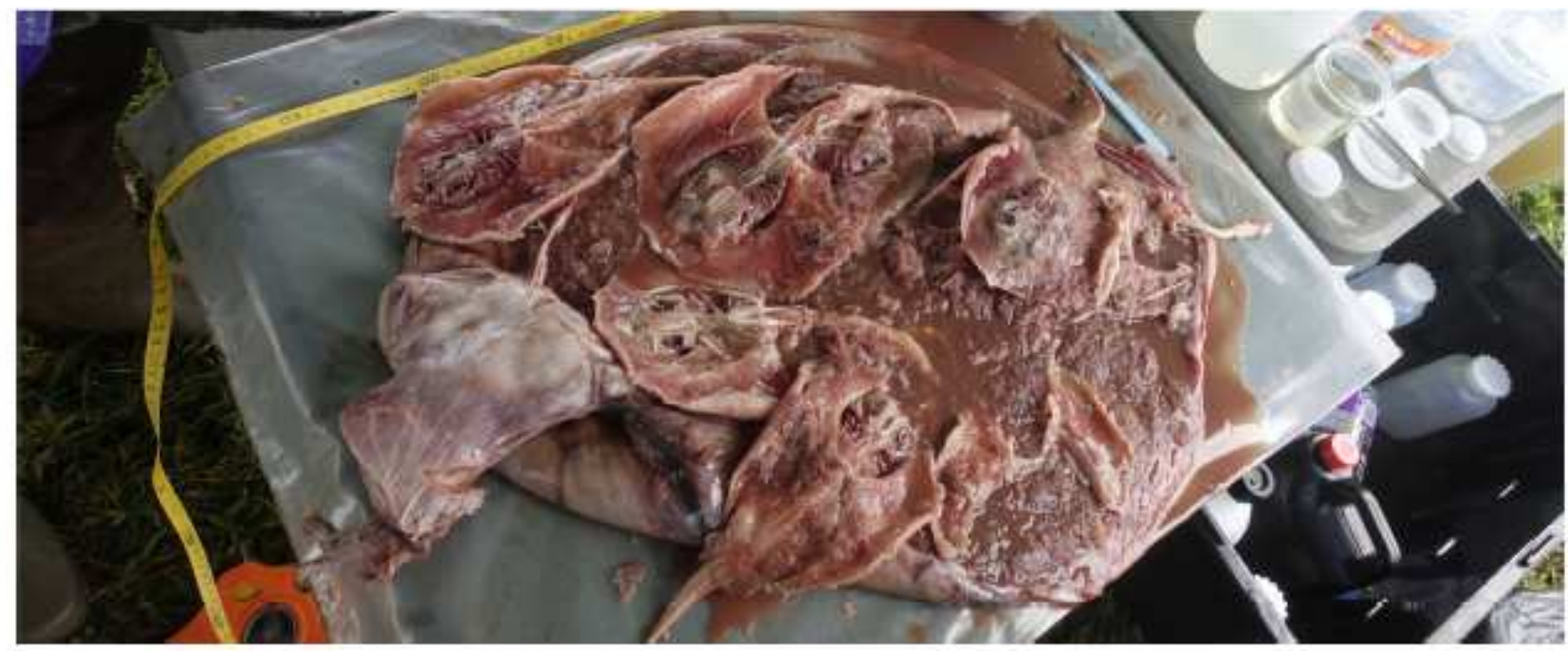

Figure 2

Photos of (a) jaw bones and (b) Urolophus sp. in the stomachs of two Sphyrna mokarran.

\section{Supplementary Files}


This is a list of supplementary files associated with this preprint. Click to download.

- deBruynetalTableS1SharkgutsSciReports.docx 